\title{
A Relentless Quest for a Paradoxical Normality: Sally Rooney's Normal People
} Mantığa Aykırı Bir Normalliğin Peşinde Amansız Bir Arayış: Sally Rooney'nin Normal People Romanı

Merve Sarıkaya-Şen

Başkent University, Turkey

\begin{abstract}
Sally Rooney's Normal People (2018) documents the complex, unstable, but, at the same time, passionate relationship between two young and intelligent individuals, Marianne Sheridan and Connell Waldron, from 2011 to 2015. While their stormy relationship goes through various separations and reattachments, Marianne follows a paradoxical quest to deal with her psychological wounds stemming from family violence and abuse in her childhood; she chooses to remain silent and adopts masochistic sexual practices. Accordingly, this study will first explore how Marianne's silence serves as a means of dealing with emotional and physical violence. It will then move onto analyse how Marianne's harrowing past of violence and abuse pushes her to adopt masochistic sexual practices that give her some relief even if temporarily. By demonstrating that Marianne's self-definition by keeping loyal to her wounds is a quest that can be defined as a paradoxical normality, this study will draw attention to one of the most important problems of our age; violence against women and their coping strategies to deal with violence.

Keywords: Sally Rooney, Normal People, violence, silence, masochism, self-definition

Öz

Sally Rooney'nin Normal People (2018) isimli romanı Marianne Sheridan ve Connell Waldron isimli iki zeki gencin arasındaki 2011'de başlayıp 2015'e kadar devam eden karmaşık, istikrarsız, fakat aynı zamanda da tutkulu ilişkiyi yazıya döker. Marianne, bir taraftan fırtınalı ilişkilerinde birçok ayrılık ve birleşme yaşarken, diğer bir taraftan da çocukluğunda yaşadığı ev içi şiddetle ve tacizden kaynaklanan psikolojik yaralanmalarıyla baş etmek için paradoksal bir yol izler; sessiz kalmayı tercih eder ve cinsel mazoşist davranışları benimser. Bu çalışmada, ilk olarak Marianne'nin sessiz kalmasının ne ölçüde duygusal ve fiziksel şiddetle savaşmaya yaradığı incelenecektir. Daha sonra ise, Marianne için hem kısa sureli rahatlık sağlayan hem de kendini tanımlamasına yardımcı olan cinsel mazoşist davranışların şiddet ve taciz tarafından nasıl tetiklendiği analiz edilecektir. Böylece, bu çalışma Marianne'in yaralarına sadık kalarak kendini tanımlamasının paradoksal normallik denebilecek bir arayış olduğunu göstererek, günümüzün en önemli sorunlarından biri olan kadına karşı şiddetin ve kadınların şiddetle baş etme yollarının altını çizecektir.
\end{abstract}

Anahtar Kelimeler: Sally Rooney, Normal People, şiddet, sessizlik, mazoşizm, kendini tanımlama 


\section{Introduction}

Why be happy when you could be normal? Jeanette Winterson (2012)

Though herself young, Sally Rooney (born 1991) is a highly praised Irish writer of two remarkable novels-Conversations with Friends (2017), winner of the 2017 Sunday Times Young Writer of the Year and Normal People (2018), winner of the Costa Prize for the Novel of the Year, Waterstones Book of the Year and An Post Irish Novel of the Year 2018. In her first critically acclaimed novel, the story revolves around the complex relationships among four characters; the narrator Frances, a twenty-one-year-old poet and student at Trinity College, Dublin; Bobbi, Frances's best friend and, at the same time, exgirlfriend; Melissa, the photographer and journalist; and Nick, Melissa's actor husband. Frances and Bobbi have an interconnected relationship which helps them to understand each other's feelings and thoughts easily even if they remain silent. When, for example, Frances suffers from period pain and locks herself in the bathroom, Bobbi slides some painkillers under the door in a soothing silence. However, their unity is fractured when they meet Melissa in one of their spoken word poetry performances. They are gradually drawn into a ménage à quatre; Bobbi takes a liking to Melissa while Frances and Nick embark on an affair that puts their relationships with Bobbi and Melissa to a test. More importantly, Frances goes through a difficult journey; she starts to question her personality, suffers from inferiority complexes, fails to nourish her self-esteem and, above all, imagines and/or inflicts self-harm once and again.

This kind of self-destruction is likewise at the centre of Normal People, which dramatizes the intense but, at the same time, conflicted and unstable sexual and emotional relationship between two young and intelligent individuals, Marianne Sheridan and Connell Waldron, from 2011 to 2015. When they are first drawn to each other, they are both in the final year of high school in County Sligo, Ireland. Marianne comes from a wealthy but emotionally poor family; she lives with her abusive brother, Alan, and her widowed mother, Denise. While Alan physically abuses and frightens Marianne-like her father who would hit her when she was a child-her mother emotionally abuses her as she believes that Marianne is unlovable and frigid. What Marianne does in response to family violence is to keep silent. To make things worse, her mother finds violence against her daughter acceptable because she thinks Marianne is devoid of warmth. Not surprisingly, Marianne turns out to internalize such physical and emotional violence during her teenage years and adulthood; she is a loner who finds herself unlovable, damaged and worthy of abusive behaviour. In contrast, Connell, a good-looking, popular and well-liked student, lives with his caring and loving single mother who works as a cleaning lady for the Sheridans. Connell is reluctant to reveal his affair with Marianne as he is afraid of losing his popularity if his friends learn about their relationship. However, when they both move to Dublin for university, they change roles; Marianne gains popularity among her friends whereas Connell only gets "the 
status of rich-adjacent" just because of his connection with Marianne (Rooney Normal People 99). At university, their relationship goes through a difficult journey as a result of misperceptions and silences between them. In the meantime, in her affairs with other men like Jamie and Lukas, Marianne discovers her inner need for abusive, demeaning, unloving, and sadistic partners who have the potential to inflict physical and emotional violence on her. Ultimately, she prefers to embrace her wounds although she finds the opportunity to have a healthy and normal relationship with Connell.

Since its publication in 2018, Rooney's Normal People has received critical reviews and analyses from various standpoints ranging from affect studies to globalism. In his review, Alan Eppel argues that Marianne and Connell experience their true selves only in their unique relationship which "keeps throwing them back together with feelings of love and sexual union" (n.p.). Similarly, Kate Clanchy states that the novel is a love story that shows the meaning of being young and in love at any time in one's life (n.p.) while Dwight Garner explores the intense love across social classes in the novel (n.p.). One step further, Annalisa Quinn looks into the possibilities of love under the effects of capitalism as represented in Normal People. According to Quinn, the novel presents the possibilities of a generous and fair country despite the inequalities and difficulties brought along by global capitalism and class differences (n.p.). Even though the novel has been analysed from these standpoints, little attention has been paid to how Marianne responds to violence exercised by her family and partners. Accordingly, this study will first analyse Marianne's silence as a source of empowerment against physical and emotional violence. In order to better understand Marianne's silent revolt, this study will reconsider violence against women, an issue that still needs to be solved globally. It will then explore how Marianne's dreadful childhood memories of abuse drag her towards masochistic practices in the long run that provide her with some relief once and again. Finally, this study will try to demonstrate that the way Marianne embraces her wounds is what defines her identity, a phenomenon that is widely recognised in twenty-first century British fiction. In doing so, this study will analyse Normal People as an exemplary contemporary British narrative that makes readers think critically about how women respond to violence and paradoxically define themselves through their wounds.

\section{Silence as a Form of Nonviolence}

As outlined above, one of the defining characteristics of Normal People is violence against Marianne, a vulnerable woman exposed to her family's and partners' physical and sexual abuse. In the $O E D$, violence is defined as "the exercise of physical force so as to inflict injury on, or cause damage to, persons or property; action or conduct characterized by this; treatment or usage tending to cause bodily injury or forcibly interfering with personal freedom" (n.p.). As the critics Jane Kenway and Lindsay Fitzclarence state, violence "occurs along a continuum and involves physical, sexual, verbal and emotional abuses of power at individual, group and social structural levels" (117). What 
deserves great attention is that violence that is carried out either through physical force or attitudes is not only concerned with physical damage to the body but also with the possible loss of personal freedom. For what purposes and by whom violence is defined turns it into a more complex issue though. As literary critic Sarah Cole explains, violence has been considered a point of origin not only by ancient cultures and religions but also by modern nations as seen in wars or large-scale events which have resulted in the killing or destruction of vulnerable people (3). Besides, although various nations have resorted to violence in order to protect their countries or obtain their freedom, the result is not always victorious, triumphant, or complete (Cole 3). To put it differently, violence that is used in the name of defending or founding one's country has unsurprisingly resulted in failure and destruction, especially when considering its implications for minorities and vulnerable groups.

Unfortunately, nothing much has changed in the twenty-first century that has been witnessing various forms of violence against vulnerable people including women all over the world. The United Nations defines violence against women as "any act of gender-based violence that results in, or is likely to result in, physical, sexual, or mental harm or suffering to women, including threats of such acts, coercion or arbitrary deprivation of liberty, whether occurring in public or in private life" (2). According to a recent study by the World Health Organization (WHO), one in three women are exposed to such acts of violence globally, which leaves a profound impact on their physical and mental health (WHO "Addressing Violence" 2). Women might be exposed to these violent attacks at any stage of their lives in different forms. In its report on violence and health, WHO divides violence into three broad categories depending on who commits violence; self-directed violence, interpersonal violence and collective violence (WHO "World Report"4). Self-directed violence is concerned with suicidal behaviour and self-abuse; interpersonal violence includes family and/or intimate partner violence and community violence; and collective violence is exercised by a group of people against another group of individuals (WHO "World Report" 4-5). Although any form of violence against women has been widely recognized as a human rights issue, it is still a pervasive and salient problem that needs to be solved as represented in twenty-first century fiction. These works include but are not only limited to those written by Irish women writers; Marian Keyes's This Charming Man (2008), Eimear McBride's A Girl is a Half-Formed Thing (2013), Anna Burns's Milkman (2018) and Rooney's Normal People are just to name a few.

As a solution to fight against violence, contemporary fiction has presented the strategy of silence, which can be taken as a form of nonviolence. In her recently published work The Force of Nonviolence (2020), Judith Butler argues that the only way of finding a life in our contemporary world saturated with inequities and violence is adhering to the principle of nonviolence which "requires a certain leave-taking from reality as it is currently constituted, laying open the possibilities that belong to a newer political imaginary" (10-11). In this context, silence might be considered as a means of nonviolence that provides the victims of violence with the possibility of detaching themselves from reality as 
it is currently established. Although usually associated with the absence of speech, silence is regarded as a communicative and polyphonic mechanism against violence, especially by feminist scholars. According to Nancy Bonvillain, silence is an instrument of nonverbal communication, as it "transmits many kinds of meaning dependent on cultural norms of interpretation" and "conveys meaning, as does all communication, partly from the situational and interactional contexts of its use" (38). When considering its implications for feminist studies, silence is a discourse that conveys various meanings ranging from passivity and oppression to resistance, agency, persistence, subversion, defiance and transformation, depending on cultural, social, and rhetorical mechanisms. Social feminists like Marsha Houston and Cheris Kramarae argue that women's silence prolongs their oppression and passivity because silent women tend to remain disconnected from the rest of the society and face mistreatment and oppression in the long run (389-393). Therefore, as Adrienne Rich states, they might have to deal with "namelessness, denial, secrets, taboo subjects, erasure, false-naming, non-naming, encoding, omission, veiling, fragmentation and lying" (18). However, feminists like Debra A. Castillo and Jane L. Parpart or Swati Parashar underline the empowerment gained through silence. Drawing on a distinction between silence as a condition imposed from the outside and a freely chosen strategy, Castillo argues that women use "the mask of silence to slip away. Silence, once freed of the oppressive masculinist-defined context of aestheticized distance and truth and confinement and lack can be reinscribed as a subversive feminine realm" (40). Similarly, Parpart and Parashar argue that silence can be a choice, a coping mechanism to deal with toxic and/or dangerous situations as well as a source of agency and empowerment (4). Thus, critics like Castillo, Parpart and Parashar approach silence from a different perspective and underline its transformative potential, especially for women exposed to violence in any form in contrast to its oppressive effects on their lives.

In Normal People, silence turns out to be a coping mechanism for Marianne to deal with her family members' physical and/or emotional violence once and again. For example, when she is physically abused by her brother-he questions her insistently, holds her tightly by the upper arm and drags her back from the door-the only thing she does is to keep silent and put on a placid but, at the same time, insolent smile (Rooney Normal People 9-10). Similarly, she retreats into silence against her mother's emotional abuse: "Denise decided a long time ago that it is acceptable for men to use aggression towards Marianne as a way of expressing themselves" (65). Although Marianne tries to fight against her mother's attitude in her childhood, later on in her adulthood she "simply detaches, as if it isn't of any interest to her, which in a way it isn't" (65). Instead of trying to show any reaction against her mother and brother or speak about what she has gone through, Marianne prefers to isolate herself and keep silent.

As we learn in the following pages, Marianne's silent revolt against both her brother and mother is not imposed from the outside but is a freely chosen activity. For example, when she studies at university, her friends prefer to 
celebrate Christmas with their families. In contrast, Marianne decides to keep away from them not only for Christmas but forever: "she imagines scenarios in which she is completely free of her mother and brother, on neither good nor bad terms with them, simply a neutral non-participant in their lives" (195). Marianne's scenarios of retreating into her shell are not only based on her imagination but originate from her real-life experiences:

She spent much of her childhood and adolescence planning elaborate schemes to remove herself from family conflict: staying completely silent, keeping her face and body expressionless and immobile, wordlessly leaving the room and making her way to her bedroom, closing the door quietly behind her. Locking herself in the toilet. Leaving the house for an indefinite number of hours and sitting in the school car park by herself. (195)

In doing so, Marianne chooses to use her silence as a source of empowerment that helps her to escape from abuse and its aftereffects even if for a short time. As suggested by Castillo, Parpart and Parashar, silence is a coping mechanism for women. In this sense, silence helps Marianne to dissociate herself from abusive and violent behaviour of her family and provides her with a different realm of her own. However, her experiences of childhood and teenage abuse move Marianne from silence towards masochistic sexual practices in her adulthood as she believes her body is the only space to express herself and enjoy her individual freedom.

\section{Childhood Abuse and Masochism}

Since its conceptualisation in the nineteenth century by Richard von KrafftEbing, masochism has been a much debated issue. In his analysis of the sexual abnormalities of the protagonist Severin von Kusiemski in Leopold von SacherMasoch's Venus in Furs (1869) who willingly submits himself to abuses, mistreatments, and humiliations of the merciless Wanda von Dunajew, KrafftEbing defines masochism as "the wish to suffer pain and be subjected to force ... the idea of being completely and unconditionally subject to the will of a person of the opposite sex; of being treated by this person as by a master, humiliated and abused" (131). Among people most prone to masochistic tendencies are those exposed to early childhood abuse. As Judith Lewis Herman argues, survivors of abuse in childhood "are particularly vulnerable to repeated harm, both self-inflicted and at the hands of others" (119). On the one hand, these children exposed to abuse inflict harm on themselves because this is the only form of love they know. As Bernhard Berliner states, "the dependent child ... submits and accepts the suffering ... In this way, the masochistic person has learned to gravitate toward punitive others because this is the only kind of intimacy that he or she knows" (461). Not surprisingly, when these children grow up, they adopt a pathological way of loving and tend to be involved in problematic relationships that repeatedly drag them towards self-destruction and victimhood. 
On the other hand, some of these victims might have recourse to masochistic practices because they want to gain control over their harrowing childhood memories of abuse and try to relieve themselves, even if for a short time. Sigmund Freud traces the rationale behind masochistic practices in the subject's need to gain mastery over an unwillingly experienced event, especially in childhood. In this context, Freud draws a correlation between masochistic practices and his grandson Ernest's fort-da game in which he repetitively throws a toy out of sight because of his mother's abandonment of him:

At the outset, he [the child] was in a passive situation--he was overpowered by the experience; but, by repeating it, unpleasurable though it was, as a game, he took on an active part. These efforts might be put down to an instinct for mastery that was acting independently of whether the memory was in itself pleasurable or not. (15)

Thus, the child masters activity and agency over his undesirable experience of being abandoned. Following in the footsteps of Freud and Herman, Glen 0. Gabbard states that "[p]atients who re-create the abusive and humiliating experiences from childhood are re-working a traumatic experience, but this time on their own terms with themselves in the driver's seat" (104). One step further, Novick and Novick argue that "masochism is the active pursuit of psychic or physical pain, suffering, or humiliation in the service of adaptation, defence, and instinctual gratification at oral, anal, and phallic levels" (261). Similarly, Robert D. Stolorow emphasizes that masochism has the "function of restoring and sustaining the cohesiveness, stability and positive affective colouring of a precarious, threatened, damaged or fragmenting selfrepresentation" (447). As suggested in these lines, masochism does not necessarily signify merely pleasure in pain but provides the subject with the potential for gaining mastery over an agonizing past and re-affirming selfcohesion.

In Normal People, Rooney presents a telling example of masochism stemming from childhood abuse through a portrayal of Marianne's precarious and fragmented self-perception. Under the influence of her childhood memories imbued with her father's, brother's and mother's abusive treatments, Marianne believes she is an unlovable and cold person who deserves to be treated badly (133). Besides, she is disconnected from life: "Marianne had the sense that her real life was happening somewhere very far away, happening without her" (11). She also feels that she is quite different from the people around her: "I don't know why I can't be like normal people ... I don't know why I can't make people [like her brother and mother] love me" (181). For example, when Marianne's brother tells her to kill herself as she has no friends, the only thing her mother does is to say "don't encourage her" (182). Feeling ostracized by her family, Marianne embarks on a relentless quest to find her real life and get closer to normality that she paradoxically identifies with adopting masochistic relationships. As she confesses to Jamie, she is submissive to her partners: "I like guys to hurt me" (138). Although she does not respect Jamie for tying her 
up and beating her with various objects, she is motivated by "an overwhelming desire to be subjugated and in a way broken" (13). In line with Herman's arguments, Marianne, a victim of childhood abuse, is vulnerable to harm at the hand of others like Jamie; she cannot help submitting herself to his abusive treatments. Thus, she is inclined towards a punitive lover and adopts a pathological affair because this is the only form of intimacy that she knows.

At the same time, however, masochistic sexual practices provide Marianne with some kind of relief even if temporarily. In her next affair with Lukas, Marianne is engaged in severe and violent masochistic sexual practices: "He [Lukas] squeezes her throat slightly and she coughs. Then, not speaking, he lets go of her. He takes up the cloth again and wraps it as a blindfold around her eyes ... and she feels sick" (197). According to Lukas, they are enjoying a game in which Marianne is not allowed to respond at all: "If she breaks the rules, she gets punished later" (190). Besides, Lukas repeatedly uses demeaning words to address her: "You're worthless ... You're nothing. And she feels like nothing, an absence to be forcibly filled in" (190). Although she does not like the way he speaks, "it relieves her somehow... She experiences a depression so deep it is tranquillising" (190). Echoing Stolorow's and Novick and Novick's promotions of masochism in the service of restoring a damaged identity and sustaining cohesiveness, Marianne gains some kind of relief and a way out of her depression by opting for a masochistic sexual affair with Lukas. Her choice confirms that masochism provides the subject with positive affects though for a short period of time.

\section{Embracing Wounds of the Past}

Along with their soothing effects, Marianne's masochistic tendencies are her self-defining features as reflected in her relationship with Connell. Marianne is submissive to Connell, but, unlike Jamie or Lukas, Connell refrains from getting engaged in masochistic practices with her. The passion between Marianne and Connell drives them towards a stormy relationship which goes through many separations and re-attachments. When they are reunited for the last time, Marianne asks Connell to hit her during their sexual intercourse. In line with Marianne's gradual transformation into a masochistic person, this is not surprising though. As Connell believes it would be weird to hit her, he declines Marianne's request, which makes her stop having sex with him and realize that they have become different people over the course of years:

Connell has been growing slowly more adjusted to the world, a process of adjustment that has been steady if sometimes painful, while she herself has been degenerating, moving further and further from wholesomeness, becoming something unrecognisably debased, and they have nothing left in common at all. (238-239)

Thus, Marianne accepts the fact that it is impossible for her to change the person she has become; she is a masochist with a damaged and fragmented personality. One step further, Connell's patient, caring, affectionate and thoughtful attitude towards Marianne makes her question his love and their 
relationship: "Was it just a game, or a favour he was doing her? Did he feel it, the way she did?" (258) What might be inferred from Marianne's questioning is that she finds it strange when she is treated well by her partner. As abusive behaviour is the only form of intimacy she knows, she cannot adapt to a healthy and loving relationship with Connell.

Accordingly, Marianne tends to embrace her wounds stemming from her abusive past instead of living a normal life with Connell that depends on mutual love and respect. When Connell openly and frankly shows his love of Marianne in public, she is disturbed as she feels that their relationship is about to metamorphose into an ordinary attachment:

How strange to feel herself so completely under the control of another person [Connell], but also how ordinary. No one can be independent of other people completely, so why not give up the attempt, she thought, go running in the other direction, depend on people for everything, allow them to depend on you, why not. (261-262)

Although Marianne gets close to turning a new page in her life by continuing an interdependent relationship with Connell, she neither chooses to rely on him nor lets him do so. As the novel draws to a close, Connell is offered a place in a creative writing program in New York and Marianne decides to stay in Ireland and insists on him leaving her (265-266). Paradoxically, however, she accepts that the only person who has brought her happiness and goodness is Connell and "what they have now they can never have back again" even if Connell returns from New York in the future (266). Thus, she does not choose to have an interdependent relationship with Connell but keeps loyal to her wounded self.

Such behaviour of Marianne's can be better understood as an example of defining the self through the wound, a mode of existing in contemporary fiction that has been addressed by Susana Onega and Jean-Michel Ganteau in their coedited work The Wounded Hero in Contemporary Fiction: A Paradoxical Quest (2018). As they brilliantly state, there is "a new type of (physically and/or spiritually) wounded hero(ine) immersed in a paradoxical life quest that involves the embracing, rather than the overcoming, of suffering, alienation, and marginalisation" (7-8). Among these heroes and/or heroines are anorexic, bulimic and hysterical characters as well as the members of the gay community during the rise of the AIDS crisis, tramps and outlaws "who willingly embrace marginalisation, exclusion, suffering, and paradoxical invisibility as a form of self-definition" (Onega and Ganteau 8). Similarly, in Why Be Happy When You Could Be Normal? (2012) Jeanette Winterson states that "all my life I have worked from the wound. To heal it would mean an end to one identity-the defining identity" (223). In that sense, Onega and Ganteau list such wounded heroes and heroines in contemporary fiction as Lisa Genova's Still Alice (2007), Alan Hollinghurst's The Stranger's Child (2011), Jon McGregor's So Many Ways to Begin (2007) and Jeanette Winterson's The Gap of Time (2015) (12). However, this does not mean that the figure of the wounded hero(ine) is only visible in twenty-first literature. As Onega and Ganteau argue, "classical 
literature is full of examples of incomplete, orectic characters, and so are the protagonists of Medieval, (early-) Modern, and contemporary romance who are systematically driven by an unending need for completeness" (Onega and Ganteau 12). What is mainly observed in twenty-first century literature is that these vulnerable characters are resurrected as in the example of Marianne in Rooney's Normal People.

Marianne's wounds stemming from physical and psychological abuse in her childhood and leading to her later masochistic affairs echo Winterson's statement; Marianne has always worked from her wounds that have ultimately defined who she is. For example, when she was in high school, "the boys had tried to break her with cruelty and disregard, and in college men had tried to do it with sex and popularity, all with the same aim of subjugating some force in her personality" (192). More importantly, the way she was treated by men in her childhood and adulthood gradually define the contours of her identity marked by her physical and psychological wounds that are not possible to heal. Although she knows that her life is abnormal, she does not do anything to change it because "so much is covered over in time now, the way leaves fall and cover a piece of earth, and eventually mingle with the soil. Things that happened to her then are buried in the earth of her body" (241). Her relationship with Connell brings her goodness, which she does not want to risk by joining him in New York (265-266). However, as she defines herself through her wounds, she does not openly do anything to heal them because this would mean ending her identity. Thus, she embraces her wounds in the past and present as they are instead of changing her life by going to New York.

\section{Conclusion}

Marianne's normality can be described as a paradoxical quest to define herself through her wounds. The novel documents how Marianne's harrowing childhood memories of abuse gradually trigger her masochistic practices. In her childhood, when she is exposed to abusive behaviour of her family, she retreats into silence that gives her the freedom to dissociate herself from the present reality and create a world of her own. As she grows up, her silence transforms into masochistic sexual practices; she enjoys submitting herself to her boyfriends. Her masochistic practices are not only a source of pleasure though. They provide her with some kind of relief even if temporarily. Accordingly, when she finds the opportunity to have a normal relationship with Connell that depends on mutual dependence and trust, she chooses to leave him. Although Connell is the only person that can give her happiness and goodness, she is faithful to her wounds. In doing so, the novel answers the question asked in the epigraph to this article. Instead of being happy, Marianne chooses to be normal that she identifies with espousing her wounds.

In that sense, Marianne's choice conforms to John Berger's famous description of art that "becomes a meeting-place of the invisible, the irreducible, the enduring, guts and honour" (9). The late twentieth- and early twenty-first centuries have been widely marked by collective wounds of a global scale, provoked either by natural disasters or human agency, including terrorism, 
radicalism, ethnic cleansing, and wars related to the process of decolonization as well as individual wounds stemming from violence and abuse against women, children, the underprivileged and the immigrants along with religious, racial, and sexual minorities (Pellicer-Ortín and Sarıkaya-Şen 315). Not surprisingly, contemporary literature has widely been concerned with explicitly presenting the predicament of such wounded figures as in the example of Rooney's Normal People. One step further, the novel brings to the fore the construction of self-identity and the possibility of paradoxical normality by relying on physical and/or psychological wounds. In doing so, the novel makes us reconsider the possibilities of leading a normal life in our contemporary world dominated by disasters and crises, especially the opportunities of life for women that are trying to find strategies to cope with violence both at collective and individual levels.

\section{Works Cited}

Berger, John. Keeping a Rendezvous. Vintage, 1992.

Berliner, Bernhard. "On Some Psychodynamics of Masochism." The Psychoanalytic Quarterly, vol.16, 1947, pp. 459-471.

Bonvillain, Nancy. Language, Culture, and Communication: The Meaning of Messages. $8^{\text {th }}$ ed., Rowman and Littlefield, 2020.

Burns, Anna. Milkman. Faber \& Faber, 2018.

Butler, Judith. The Force of Nonviolence: An Ethico-political Bind. Verso, 2020.

Castillo, Debra Ann. Talking Back: Toward a Latin American Feminist Criticism. Cornell UP, 1992.

Clanchy, Kate. "Normal People by Sally Rooney Review - A Future Classic." The Guardian, 1 Sept. 2018, https://www.theguardian.com/books/2018/sep/01 /normal-people-sally-rooney-review

Cole, Sarah. At the Violet Hour: Modernism and Violence in England and Ireland. Oxford UP, 2012.

Eppel, Alan. "Normal People: The Self-at-worst and the Self-at-best." Journal of Psychiatry Reform, 4 July 2020, https://journalofpsychiatryreform.com/ 2020/07/05/normal-people.

Freud, Sigmund. "Beyond the Pleasure Principle." The Standard Edition of the Complete Psychological Works of Sigmund Freud, edited and translated by James Strachey, Anna Freud, Alix Strachey and Alan Tyson, vol.18, 2001 (1920), Vintage, pp.7-66.

Gabbard, Glen 0. "Masochism as a Multiply-determined Phenomenon." The Clinical Problem of Masochism, edited by Deanna Holtzman and Nancy Kulish, Jason Aronson, 2012, pp.103-112.

Ganteau, Jean-Michel and Susana Onega. Introduction. The Wounded Hero in Contemporary Fiction: A Paradoxical Quest, edited by Susana Onega and JeanMichel Ganteau, Routledge, 2018, pp.1-15.

Garner, Dwight. "Sally Rooney's 'Normal People' Explores Intense Love Across Social Classes." The New York Times, 8 April 2019, https://www.nytimes.com/2019/ 04/08/books/review-normal-people-sally-rooney.html. 
Genova, Lisa. Still Alice. Pocket Books eBook., 2007.

Herman, Judith Lewis. Trauma and Recovery. Basic Books, 1992.

Hollinghurst, Alan. The Stranger's Child. Picador, 2011.

Houston, Marsha and Cheris Kramarae. "Speaking from Silence: Methods of Silencing and of Resistance." Discourse and Society, vol. 2, no. 4, 1991, pp. 387-399.

Kenway, Jane and Lindsay Fitzclarence. "Masculinity, Violence and Schooling: Challenging Poisonous Pedagogies." Gender and Education, vol.9. no.1, 1997, pp. 117-134.

Keyes, Marian. This Charming Man. HarperCollins, 2008.

Krafft-Ebing, Richard von. Psychopathia Sexualis: A Medico-forensic Study. William Heinemann, 1939.

McBride, Eimear. A Girl is a Half-formed Thing. Faber \& Faber, 2013.

McGregor, Jon. So Many Ways to Begin. Bloomsbury, 2007.

Novick, Kerry Kelly and Jack Novick. "The Essence of Masochism." Essential Papers on Masochism, edited by Margaret Ann Fitzpatrick Hanly, New York University Press, 1995, pp. 237-264.

Oxford English Dictionary. https://www.oed.com/oed2/00277885.

Quinn, Annalisa. “The Small Rebellions of Sally Rooney's Normal People." The Atlantic, 12 April, 2019, https://www.theatlantic.com/entertainment/archive/2019/04/ sally-rooneys-normal-people-review/586801.

Parpart, Jane L. and Swati Parashar. "Introduction: Rethinking the Power of Silence in Insecure and Gendered Sites." Rethinking Silence, Voice and Agency in Contested Gendered Terrains, edited by Jane L. Parpart and Swati Parashar, 2018, Routledge, pp.1-15.

Pellicer-Ortín, Silvia and Merve Sarıkaya-Şen. "Introduction. Contemporary Literature in Times of Crisis and Vulnerability: Trauma, Demise of Sovereignty and Interconnectedness." European Review, vol.29, no. 3, 2021, pp. 315-332. doi:10.1017/S1062798720000666

Rich, Adrienne. "The Transformation of Silence into Language and Action (A Panel Discussion)." Sinister Wisdom, vol. 6, 1978, pp. 17-25.

Rooney, Sally. Conversations with Friends. Faber \& Faber, 2017.

---. Normal People. Faber \& Faber, 2018.

Stolorow, Robert D. "The Narcissistic Function of Masochism (and Sadism)." The International Journal of Psychoanalysis, vol. 56, 1975, pp. 441-448.

The United Nations. "Declaration on the Elimination of Violence against Women Proclaimed by General Assembly Resolution 48/104." 1993, pp.1-4. https://www.un.org/en/genocideprevention/documents/atrocity-crimes/ Doc.21_declaration\%20elimination\%20vaw.pdf.

World Health Organization. "Addressing Violence against Women: Key Achievements and Priorities." 2018, pp.1-11, https://apps.who.int/iris/bitstream/handle/ 10665/275982/WHO-RHR-18.18-eng.pdf?ua=1.

World Health Organization. "World Report on Violence and Health: Summary." 2012, pp. 1-54, https://www.who.int/violence_injury_prevention/violence/world_ report/en/summary_en.pdf.

Winterson, Jeanette. Why Be Happy When You Could Be Normal? Vintage, 2012. 